\title{
ZNF224 wt Allele
}

National Cancer Institute

\section{Source}

National Cancer Institute. ZNF224 wt Allele. NCI Thesaurus. Code C126564.

Human ZNF224 wild-type allele is located in the vicinity of $19 q 13.2$ and is approximately $16 \mathrm{~kb}$ in length. This allele, which encodes zinc finger protein 224 , is involved in transcriptional repression. 